\title{
Robert Paul Churchill, Women in the Crossfire: Understanding and Ending Honor Killing (New York: Oxford University Press, 2018), ISBN 978-0-190-46856-9, 334 pages.
}

\author{
Reviewed by Sital Kalantry
}

Women in the Crossfire, a book by philosopher Paul Churchill, is a significant contribution to efforts to understand honor killing. Too many works speak generally about gender-based violence. By focusing just on one type of gender-based violence, Professor Churchill is able to give us a number of insights into the crime than would otherwise be possible. True to his philosopher roots, he spends significant time in defining honor killings and distinguishing them from other crimes, such as crimes of passion, domestic violence, and politically-motivated violence. Defining honor killings allows him to better investigate its history, scope, causes, and solutions. The author explores honor killing from an empirical, cultural, psychological, and historical perspective.

There is a dearth of existing empirical quantitative studies on honor killing. Churchill and his colleague set out to fill this gap by scouring a wide variety of materials to find reported cases of honor killings. They examine (among other things) scholarly books, journal articles, newspapers, wire service reports and online databases. With this data, Churchill does an exhaustive analysis to identify common characteristics of reported honor killings, such as motives, the relationship between the perpetrator-victim, and the ages of victims and perpetrators. Perpetrators are typically fathers and brothers of the victim and the most significant motive for the crime is when a girl or woman chooses a husband or boyfriend that is unacceptable to the family. Churchill's historical analysis suggests that honor killings are responses to mate guarding and costly signaling.

Churchill argues that honor killing occurs within what he calls "honor-shame communities." In these communities, a group of people acknowledge the same, usually unwritten honor code. The honor code is used control female bodies and women's sexuality. When a woman transgresses this honor code, she is killed as a way to restore the honor the family has lost because of the transgression. Thus, honor killing is a social practice, it cannot be separated from the community in which it occurs.

Churchill's data set includes a disproportionate number of honor killings in immigrant communities ( 1 and 4). But Churchill is careful to point out that this doesn't necessarily mean there are more honor killings among immigrant communities, but that those cases are easier to find because they garner greater media attention. The media in which those murders are reported is also probably more accessible to his researchers. Churchill does not present us with a contextual analysis that would consider the differences between honor-shame communities in migrant-receiving countries and in countries where the practice has historically occurred. In a small village in Pakistan, a family's dishonor by the act of a female relative is visible to them every day through the multiple interactions they have with neighbors, shop owners, and other relatives. That heightened sense of dishonor may not exist in immigrant communities. Immigrants live among people who do not share the same honor code and thus, do not share 
the same notions of dishonor. Of course, sometimes immigrants live in close proximity with other people who emigrated from the same country and region they have come from. In those cases, there may be a shared honor code. Moreover, immigrants often maintain relationships with people from their country of origin, which is increasingly possible as Churchill notes through text messages, phone, and social media. Yet, a more nuanced perspective would recognize that honor killings that occur among immigrant communities in countries where the majority group does not share the same notions of honor/dishonor must be understood differently than honor killings in places where they have historically occurred.

The last several chapters focus on providing solutions. Churchill provides an overview and shortcomings of existing proposals such as hotlines, smart phone apps, shelters, and training initiatives. Heighted criminal penalties and better prosecution are often included in the reform proposals, but they have limited gains as time has shown. The most intriguing solution he proposes is moral change within the communities themselves. This kind of long-term social and cultural change starting from the ground-up and early on in one's life is necessary to eradicate all forms of violence against women. His idea for moral transformation then is translated into specific initiatives such as educations programs, engaging men, and empowering women through micro-finance. Many of these are the same list of activities that have been circulating around gender-violence conferences and among NGO initiatives. Ultimately, long term change requires time and while there are no fast and easy solutions, Churchill does a great job of elaborating the problem in clear, factual, and inter-disciplinary terms.

Sital Kalantry is a Clinical Professor of Law at Cornell Law School and author of Women's Rights and Migration: Sex-Selective Abortion Bans in the United States and India, published by the University of Pennsylvania Press in 2017. 